\title{
Multidisciplinary Investigation of the Imperial Gates of the 17th Century Wooden Church in Sălișca, Cluj County, Romania
}

\author{
Calin Neamtu ${ }^{1, *(1)}$, Victor Constantin Marutoiu ${ }^{2}$, Ioan Bratu ${ }^{3}$, Olivia Florena Marutoiu ${ }^{2}$, \\ Constantin Marutoiu ${ }^{2}$, Ioan Chirilă ${ }^{2}$, Mihai Dragomir ${ }^{1}$ (1) and Daniela Popescu ${ }^{1}$ \\ 1 Technical University of Cluj-Napoca, Design Engineering and Robotics, bd. Muncii, no. 103-105, \\ 400641 Cluj-Napoca, Romania; mihai.dragomir@muri.utcluj.ro (M.D.); \\ daniela.popescu@muri.utcluj.ro (D.P.) \\ 2 Babeş-Bolyai University, Faculty of Orthodox Theology, f/n Nicolae Ivan st., 400692 Cluj-Napoca, Romania; \\ marutoiu.victor@ot.ubbcluj.ro (V.C.M.); marutoiu.olivia@ot.ubbcluj.ro (O.F.M.); \\ marutoiu.constantin@ot.ubbcluj.ro (C.M.); chirila.ioan@ot.ubbcluj.ro (I.C.) \\ 3 National Institute for R\&D of Isotopic and Molecular Technologies, Street Donat, no. 67-103 Cluj-Napoca; \\ Romania; ibratu@gmail.com \\ * Correspondence: calin.neamtu@muri.utcluj.ro; Tel.: +40-740-258-225
}

Received: 26 March 2018; Accepted: 4 May 2018; Published: 10 May 2018

\begin{abstract}
One of the most beautiful elements of cultural heritage in Romanian villages is the Transylvanian wooden churches. Unfortunately, these heritage elements have experienced considerable deterioration. This paper presents the results of a project whose main goal was the scientific investigation of the Imperial Gates belonging to the wooden church in Sălișca, Cluj County, Romania. To digitally preserve and document the Imperial Gates, a scientific investigation into the wooden support and the painting materials (ground, pigments) were performed using Fourier transform infrared (FTIR) and x-ray fluorescence (XRF) spectroscopy. FTIR spectroscopy provided information about the wooden support, whereas XRF and FTIR methods were used to structurally characterize the painting materials. These structural data were correlated with the artistic, theological, and historical analysis of the religious heritage monument. Starting from the information acquired about the wooden support and the painting materials, the Imperial Gates were three-dimensional (3D) scanned using state-of-the-art laser scanners. The digitization of the Imperial Gates and the interior of the church was performed to maintain the current preservation status and disseminate this information to the public using online instruments.
\end{abstract}

Keywords: digital restoration of cultural heritage; digital preservation of Imperial Gates; lime wood; painting materials; FTIR; XRF spectroscopy; 3D scanning

\section{Introduction}

Romania was a country with lot of forests, leading to the creation of an enduring wood civilization that stretched throughout millennia. This fact is supported by the bas-reliefs visible on Trajan's Column where the houses of the Dacian people are shown. The columns are built from horizontal timber beams placed circularly; the same method that was preserved in popular Romanian architecture until present times. The same architectural style used by folk craftsmen to build cottages can also be found in buildings belonging to the Christian cult. The Romanian wooden churches represent a meeting place between popular and high art, containing records of civilization and cultural history, demonstrating the synthesis of the medieval spirituality of these people, and preserving treasures of Christian spirituality. These monuments of popular architecture must be considered as representing unity through diversity, 
with common fundamental elements and variations of constructive or decorative details that are specific to certain areas and time segments. The wooden churches are part of the cultural identity of the Romanian villages and could represent a source for local development by introducing these features into the national and international travel tours [1] or as part of the sustainable tourism and cultural identity plan for Romanian villages [2].

In Transylvania, there were no great monasteries like in Wallachia or Moldavia because no wealthy class existed to contribute to their establishment [3]. Most of the wooden churches were built in the 18th-19th centuries through the efforts of local communities, and in many cases, they were rebuilt on the same location by craftsmen. The villagers used the structural models, materials, and construction techniques used for building their own houses. The wooden churches are modest in terms of dimensions but have a privileged location in the middle of the village or on the heights that dominate the village.

In 2014, the wooden churches from Transylvania and Oltenia were placed on the list of "Seven most endangered" by the Europa Nostra and European Investment Bank Institute [4], which stated that "at present, around $80 \%$ of these churches are abandoned, and some became cemetery chapels, these sacred buildings are also threatened by inadequate conservation."

The "Holy Archangels Michael and Gabriel" wooden church (Figure 1) in the Sălișca village, Câțcău parish, Cluj County, Romania was built in the northern part of the village and dates back to 1680 . The church consists of three chambers: the narthex, the nave, and the polygonal sanctuaries. Above the narthex, the prismatic spire ascends to a crown with a tapered crest. The access door is placed on the southern side, flanked by simple but massive posts. The door frames are decorated with rope, cross, and rosette symbols. The narthex has a ceiling, whereas the apse of nave and sanctuary apse are covered by a semi-cylindrical arch. The inner paintings, Imperial Gates, and icons were painted at the end of the 18th century by Popovici. On the eastern side of the sanctuary apse, the following inscription can be found: "This altar was painted by the handiness and work of the priest Oanca ... and Alexandru Popovici, the painter". This painter was active around $1790[5,6]$. Instruments like x-ray fluoroscopy (XRF) [7], Fourier transform infrared (FTIR) spectroscopy [8], x-ray diffraction/scanning electron microscope (XRD/SEM) [9], and Raman spectroscopy [10] have been used to investigate the art and archaeological objects. Several papers were dedicated to the scientific investigation of some religious art objects [11] like: wooden [12] and glass icons [13,14], diptych [15] and triptych icons [16], old wooden stalls [17], mural paintings [18-20], and Imperial Gates [21-24]. Databases for painting materials for different art objects have also been presented [12].

Rural cultural heritage in Romania is relatively undervalued, with the exception of a few tourist destinations in Transylvania and Moldova. For this reason, the digital restoration and online dissemination of three-dimensional (3D) models of the Imperial Gates will contribute to the creation of an improved image and a better touristic exposure of these monuments.

After digitizing the Imperial Gates, the images can be used in various ways for promoting cultural heritage. For example, they can be integrated into a 3D model of the church [25] or used for the development of virtual museums [26,27], the creation of special applications [28], or the application of specific engineering instruments, both software and hardware, that can lead to the generation of physical replicas by using additive manufacturing processes [29]. The development of complex applications like the one presented in $[27,30]$ requires advanced knowledge in fields such as restoration and conservation [31], reverse engineering and new product development [32,33], programming and 3D modeling [34], which can only be covered with the help of interdisciplinary teams. The 3D model of the Imperial Gates can be used also for educational, research, or other purposes [35] such as cyber archaeology, cyber archaeometry, virtual worlds, and augmented and immersive realities [36]. The images can be part of the Romanian cultural digital heritage with social implications [37] for the efforts to rescue and preserve the wooden churches in Transylvania. 


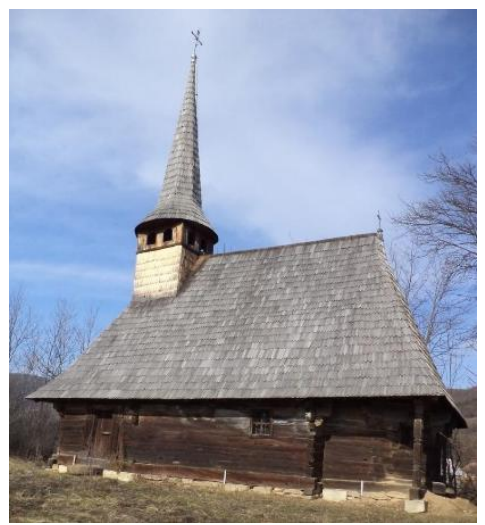

Figure 1. Wooden church from Sălișca village, Romania.

The development of complex applications as previously presented $[27,30]$ requires advanced knowledge in fields such as restoration and conservation [31], reverse engineering and new product development [32,33], and programming and 3D modeling [34], that can only be accomplished with the help of interdisciplinary teams.

The aim of this paper was to scientifically investigate the painting materials of the Imperial Gates of the wooden church from Sălișca to preserve and restore them in the digital environment. FTIR, XRF spectroscopy and 3D scanning procedures were applied for this purpose.

\section{Investigation Methods}

To scientifically evaluate the Imperial Gates of the Sălişca wooden church, an interdisciplinary team was created. The team included theologians, experts in the Romanian sacred art, experts in the arts, chemists, and engineers. Based on the methodology presented in Figure 2, the team followed a series of stages that allowed the identification of the pigments from the paint layer and the type of wood used to build the Imperial Gates. The working methodology is compatible with state-of-the-art procedures for digitization, restoration, maintenance, and digital reconstruction previously presented [38-41].

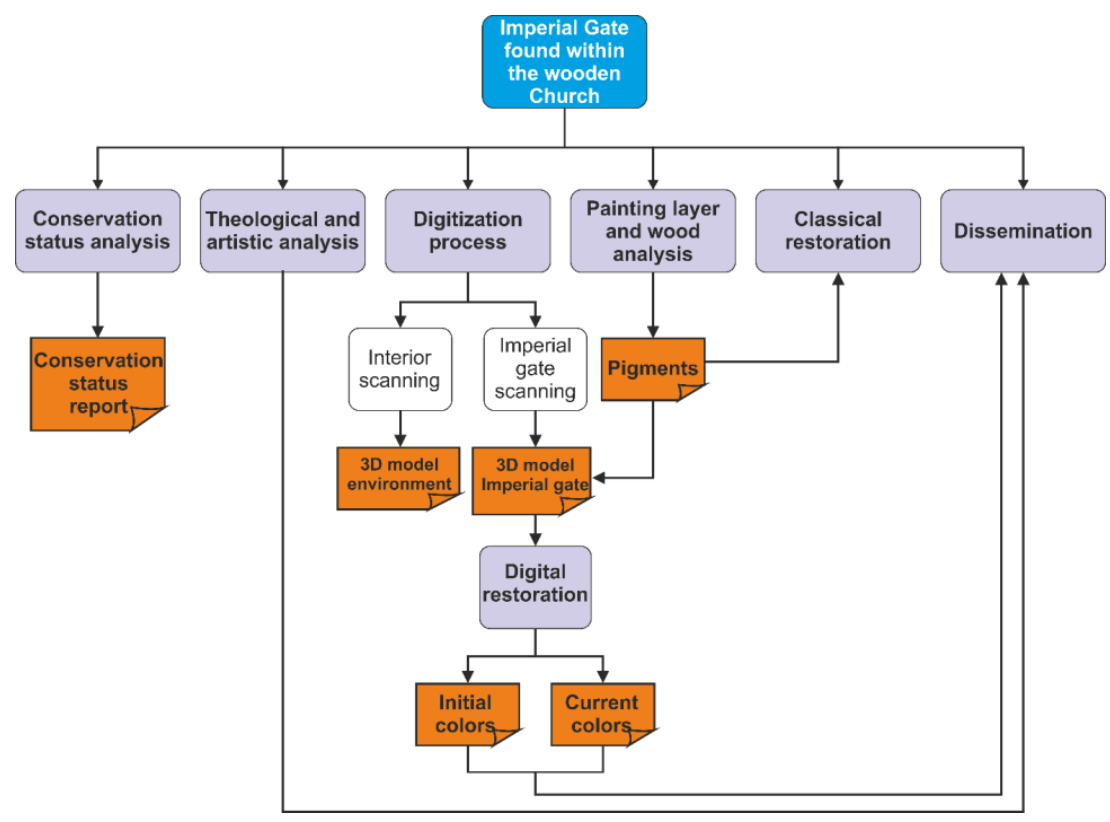

Figure 2. Work methodology. 
The methodology also focused on the digitization, digital restoration, and the promotion of the cultural heritage assets using online dissemination methods. In the first stage, the conservation status was analyzed to determine if the current state would allow their intervention and manipulation without damaging the Imperial Gates and whether they would be appropriate for classic or digital restoration. The second stage of the working methodology involved the theological and artistic analysis of the Imperial Gates to certify their value as a patrimony asset and to certify them as original assets. At this stage, we also identified the possible interventions of the restoration process of the Imperial Gates that could be performed in time. Simultaneously, the digitization and analysis of the wood support and the painting layer were performed. The digitization operation targeted both the context of the gate (the inside of the church and especially the altar) and the Imperial Gates themselves.

The analysis of the painting layer and of the wood support identified the pigment constituents to obtain these pigments by methods that are specific to the restoration process. XRF measurements were performed using an INNOV-X Alpha-6500 (Max Analyzer, Inc., Jakarta, Indonesia) portable instrument ( $35 \mathrm{kV}$ voltage, $15 \mu \mathrm{A}$ intensity, $3 \mathrm{~mm}$ filter, Be window, 2 square $\mathrm{mm}$ spot size, and PIN Si detector). Integration time was set for $60 \mathrm{~s}$ in two consecutive runs of $30 \mathrm{~s}$ each.

FTIR spectra were registered with a resolution of $4 \mathrm{~cm}^{-1}$ using a JASCO 6100 FTIR (JASCO 6100, Tokio, Japan) spectrometer in the 4000 to $400 \mathrm{~cm}^{-1}$ spectral domain by using the potassium bromide (KBr pure spectral powder) pellet technique. The spectra were processed by Spectral Analysis and Origin 8.0 software.

The 3D model resulting from the digitization, and the pigments identified in the physico-chemical analysis stage, represent the input data of the digital restoration stage, where the painting layer was restored using two scenarios: a digital restoration using a similar method to the classic state and a restoration of the painting layer with the original colors. The dissemination of the cultural heritage represented by the Imperial Gates was performed using online tools that enable real time visualization and interactivity with the 3D model to a wide audience.

\section{Results}

The Imperial Gates subjected to investigation (Figure 3) are made from pieces of lime boards. By comparing its FTIR spectrum with those of lime in Figure 4 of Marutoiu et al. [21], the boards close to the middle of the border casements are made from the same material. On the upper part of the left door, the Holy Archangel Gabriel is painted, and on the lower part is Matthew the Evangelist. On the upper part of the right door, the Virgin Mary is painted, and on the lower part is Luke the Evangelist. The painter Popovici employed a small number of colors: red, white, green, black, and blue. The pigments were investigated using XRF and FTIR spectroscopy, whereas the wood was investigated only using FTIR spectroscopy. 

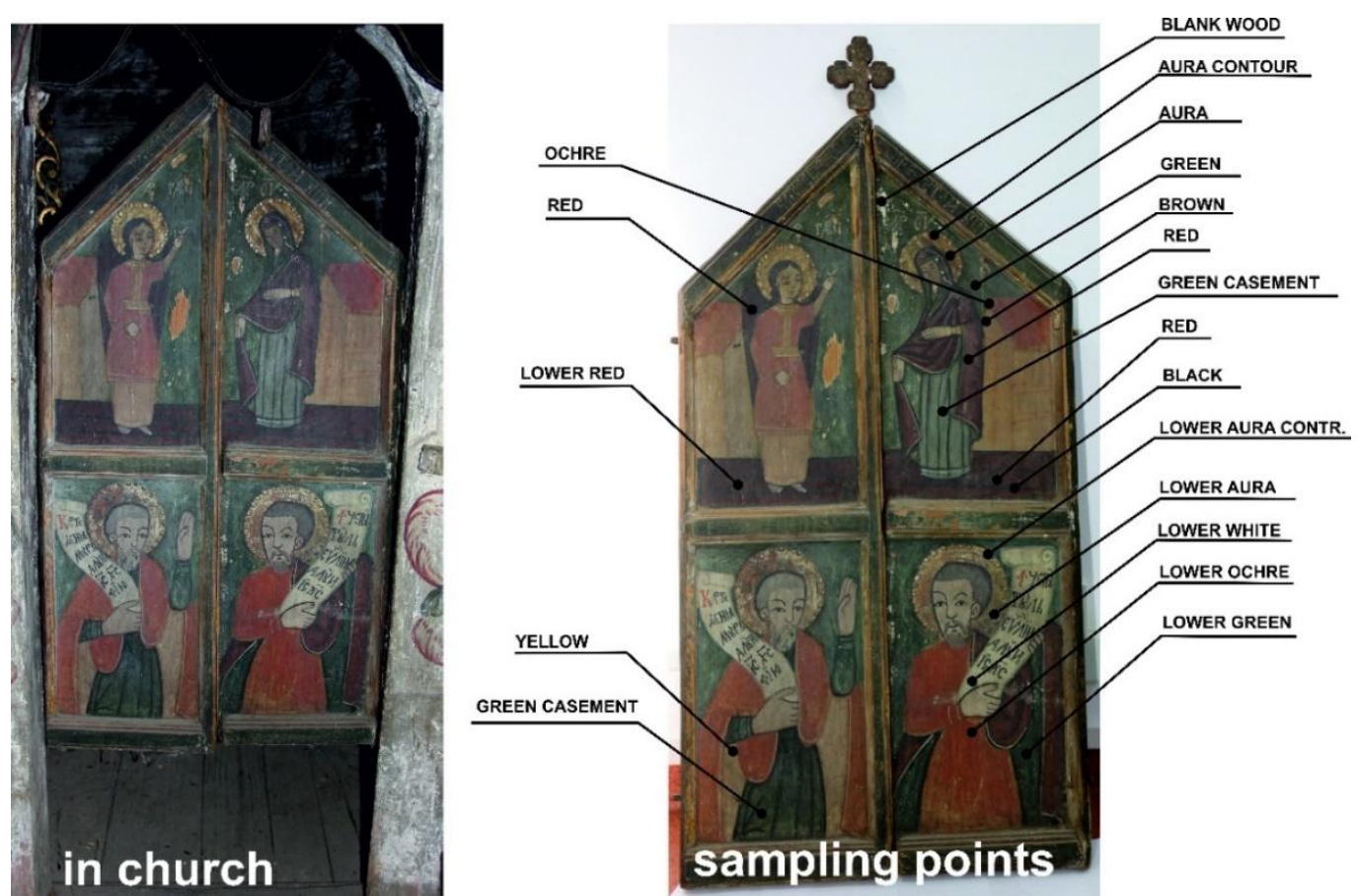

Figure 3. Imperial Gates from the Holy Archangels wooden church in Sălișca village, Cluj County, Romania.

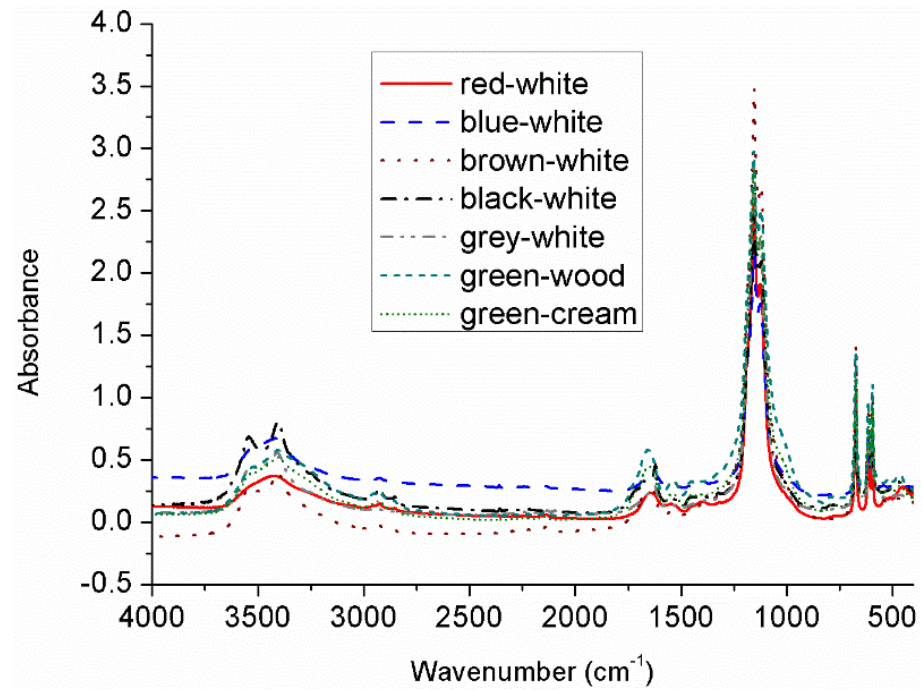

Figure 4. Fourier transform infrared spectroscopy (FTIR) spectra of painting materials, $4000-400 \mathrm{~cm}^{-1}$ spectral domain.

\subsection{XRF Results}

X-ray fluorescence measurements were performed using an INNOV-X Alpha-6500 portable instrument ( $35 \mathrm{kV}$ voltage, $15 \mu \mathrm{A}$ intensity, $3 \mathrm{~mm}$ filter, Be window, 2 square mm spot size, and PIN Si detector). Integration time was set for $60 \mathrm{~s}$ in two consecutive runs of $30 \mathrm{~s}$ each. Table 1 presents the XRF data for the investigated Imperial Gates. Gate no. 1 is on the left and Gate no. 2 is on the right. 
Table 1. X-ray fluorescence (XRF) data of the investigated Imperial Gates.

\begin{tabular}{|c|c|c|c|c|c|c|}
\hline & $\mathrm{mg} / \mathrm{kg}$ & $\mathrm{Fe}$ & As & Ag & $\mathrm{Hg}$ & $\mathrm{Pb}$ \\
\hline Gate no.1 & blank wood & $<\mathrm{LOD}$ & 2423 & $<\mathrm{LOD}$ & 66 & 22 \\
\hline Gate no.1 & green & 1364 & 4092 & $<$ LOD & $<\mathrm{LOD}$ & 363 \\
\hline Gate no.1 & red & 846 & 4268 & $<\mathrm{LOD}$ & 283 & 17804 \\
\hline Gate no.1 & brown & 36442 & 631 & $<\mathrm{LOD}$ & $<\mathrm{LOD}$ & 336 \\
\hline Gate no.1 & aura & 2598 & 251 & 579 & $<\mathrm{LOD}$ & 583 \\
\hline Gate no.1 & aura contour & 2516 & 346 & 377 & $<\mathrm{LOD}$ & 723 \\
\hline Gate no.1 & black & 5035 & 862 & 77 & 46 & 2789 \\
\hline Gate no.1 & green casement & 1132 & 4930 & $<\mathrm{LOD}$ & 70 & 122 \\
\hline Gate no.1 & lower aura & 2978 & 124 & 145 & $<$ LOD & 265 \\
\hline Gate no.1 & $\begin{array}{l}\text { lower aura } \\
\text { contour }\end{array}$ & 2509 & 176 & 422 & $<\mathrm{LOD}$ & 306 \\
\hline Gate no.1 & lower green & 1828 & 7003 & $<\mathrm{LOD}$ & 101 & 227 \\
\hline Gate no.1 & ochre & 1071 & 8452 & $<$ LOD & 370 & 42888 \\
\hline Gate no.1 & lower white & 518 & 6843 & $<\mathrm{LOD}$ & 463 & 30326 \\
\hline Gate no.1 & lower casement & 1766 & 7562 & $<\mathrm{LOD}$ & 77 & 149 \\
\hline Gate no.1 & lower ochre & 530 & 4715 & $<\mathrm{LOD}$ & 381 & 19924 \\
\hline Gate no.1 & lower black & 756 & 5863 & $<\mathrm{LOD}$ & 529 & 26837 \\
\hline Gate no.2 & red & 17853 & 4430 & $<$ LOD & 337 & 17264 \\
\hline Gate no.2 & green casement & 1147 & 5065 & $<\mathrm{LOD}$ & 73 & 98 \\
\hline Gate no.2 & yellow & 685 & 1287 & $<\mathrm{LOD}$ & 119 & 5111 \\
\hline Gate no.2 & red & 914 & 6447 & $<\mathrm{LOD}$ & 511 & 29296 \\
\hline Gate no.2 & lower red & 5241 & 4207 & $<\mathrm{LOD}$ & 400 & 18801 \\
\hline
\end{tabular}

\subsection{FTIR Results}

FTIR spectra were registered with a resolution of $4 \mathrm{~cm}^{-1}$ using a JASCO 6100 FTIR spectrometer in the 4000 to $400 \mathrm{~cm}^{-1}$ spectral domain by using $\mathrm{KBr}$ ( $\mathrm{KBr}$ pure spectral powder) pellet technique. The spectra were processed by Spectral Analysis software.

Copper ions were not detected, having small concentrations $(<100 \mathrm{mg} / \mathrm{kg})$. Based on this analysis (Table 1), the following composition of the painting materials is proposed: green results from the mixture of Prussian blue and yellow (orpiment; red-iron red, realgar, and lead red; brown-iron oxide; black-iron oxide; hallo-silver foil and bolus; and ochre-lead yellow). FTIR spectra of the investigated painting materials, together with the characteristic absorption bands of different components, are presented in Figures 4-7, including the whole spectral range and in several specific spectral domains.

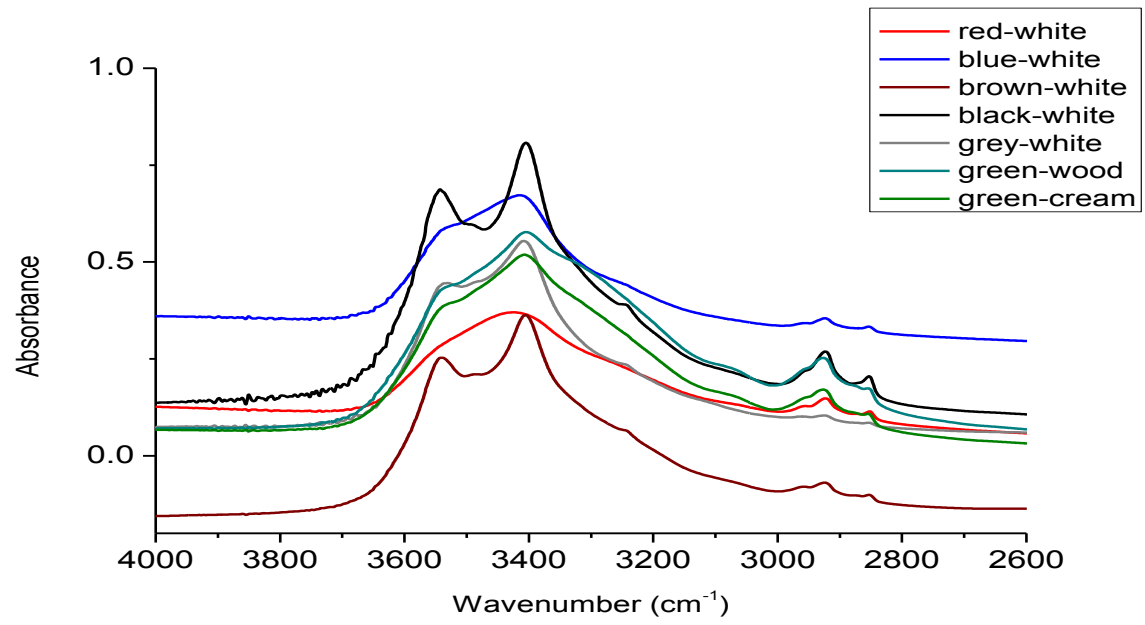

Figure 5. FTIR spectra of painting materials, $4000-2600 \mathrm{~cm}^{-1}$ spectral domain. 


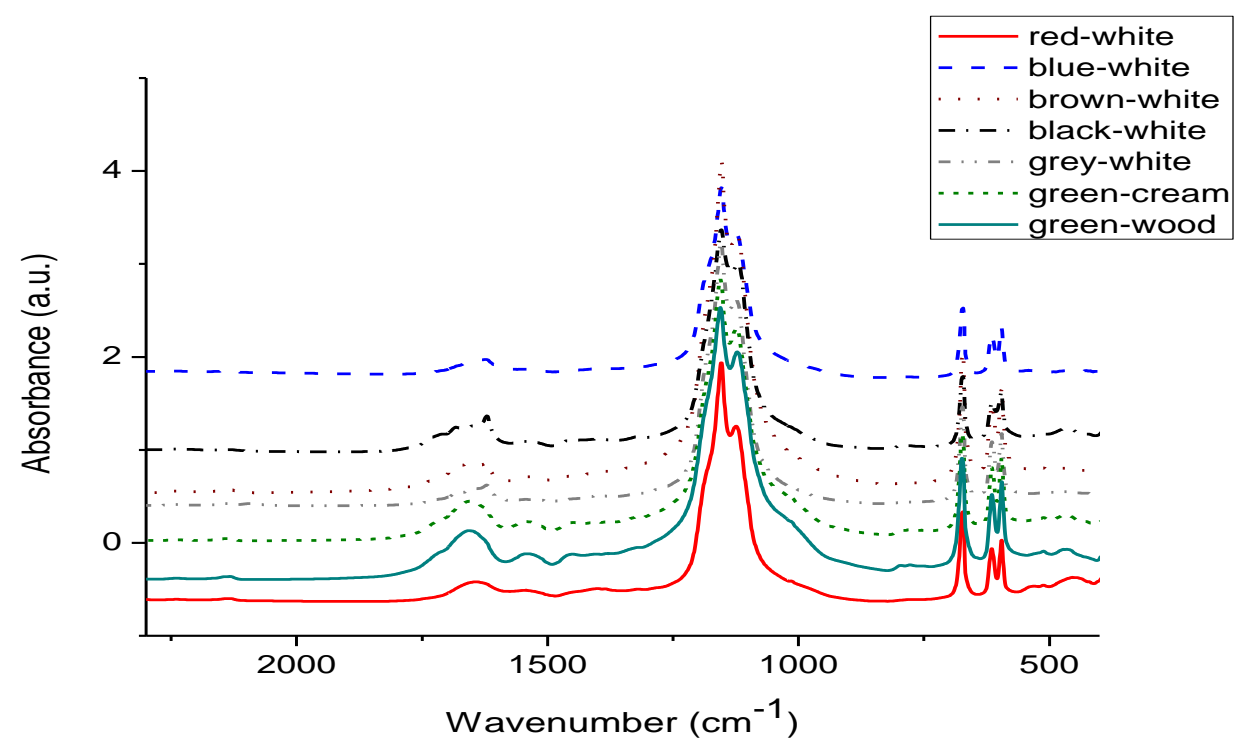

Figure 6. FTIR spectra of painting materials, $2300-400 \mathrm{~cm}^{-1}$ spectral domain.

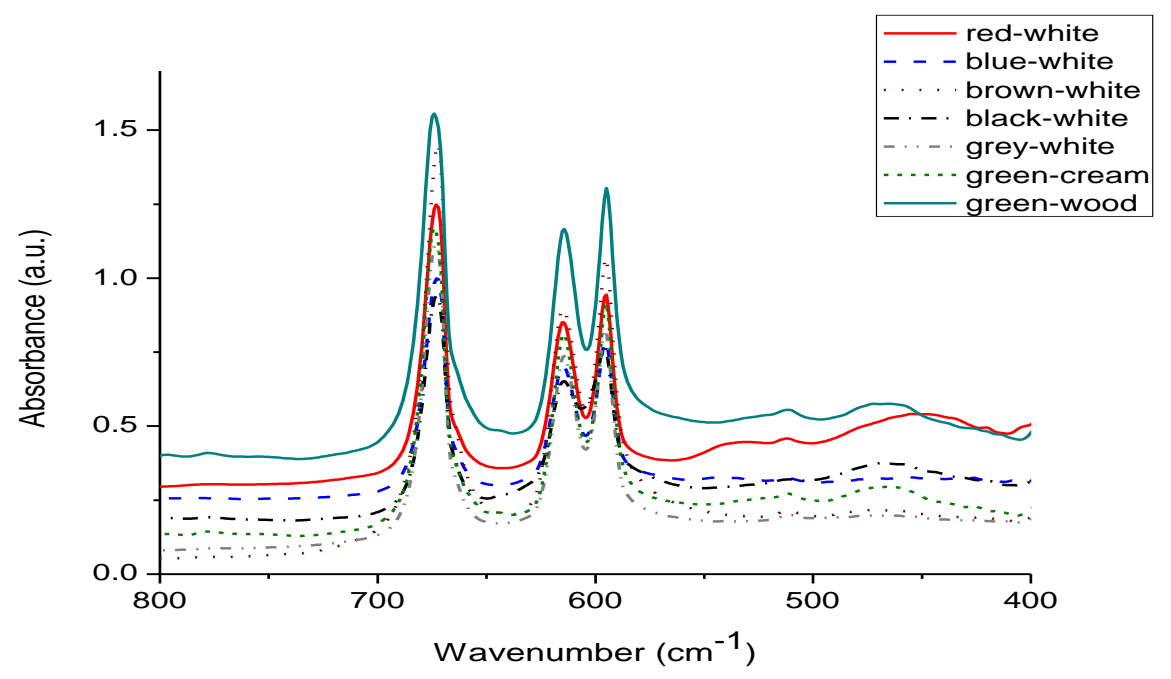

Figure 7. FTIR spectra of painting materials, $800-400 \mathrm{~cm}^{-1}$ spectral domain.

FTIR vibrational frequencies assignments and possible composition are outlined in Table 2. 
Table 2. Vibrational frequencies assignments of the investigated Imperial Gates.

\begin{tabular}{|c|c|}
\hline Color & Composition \\
\hline Red-white & $\begin{array}{c}\text { O-H stretching of gypsum }\left(3423 \mathrm{~cm}^{-1}\right) \text {, aliphatic }\left(2924 \text { and } 2856 \mathrm{~cm}^{-1}\right) \mathrm{H}-\mathrm{O}-\mathrm{H} \\
\text { bending }\left(1639 \mathrm{~cm}^{-1}\right) \text {, proteins }\left(1639 \text { and } 1543 \mathrm{~cm}^{-1}\right) \text {, lead carbonate } \\
\left(1400 \mathrm{~cm}^{-1}\right) ; \operatorname{gypsum}\left(1154,1129,615 \text {, and } 595 \mathrm{~cm}^{-1}\right) \text {, red lead }(512 \text { and } \\
\left.454 \mathrm{~cm}^{-1}\right)\end{array}$ \\
\hline Blue-white & $\begin{array}{c}\text { Gypsum }\left(3416,1623,1156,1124,615 \text {, and } 595 \mathrm{~cm}^{-1}\right) \text {, traces of aliphatics, traces } \\
\text { of Prussian blue }\left(2133 \mathrm{~cm}^{-1}\right)\end{array}$ \\
\hline Brown-white & $\begin{array}{c}\text { Gypsum }\left(3416,1622,1156,1124,615 \text {, and } 595 \mathrm{~cm}^{-1}\right) \text {, proteins }(1649 \text { and } \\
\left.1541 \mathrm{~cm}^{-1}\right) \text {, traces of red lead }\left(514 \text { and } 474 \mathrm{~cm}^{-1}\right)\end{array}$ \\
\hline Black-white & $\begin{array}{l}\text { Gypsum }\left(3543,3405,1621,1154,1129,615 \text {, and } 595 \mathrm{~cm}^{-1}\right) \text {, protein }(1541 \text { and } \\
\left.1322 \mathrm{~cm}^{-1}\right) \text {, aliphatic }\left(2924 \text { and } 2856 \mathrm{~cm}^{-1}\right) \text {, lead carbonate }\left(1403 \text { and } 673 \mathrm{~cm}^{-1}\right)\end{array}$ \\
\hline Grey-white & $\begin{array}{l}\text { Gypsum }\left(3543,3405,1621,1154,1129,615 \text {, and } 595 \mathrm{~cm}^{-1}\right) \text {, traces of lead } \\
\text { carbonate }\left(1399 \text { and } 673 \mathrm{~cm}^{-1}\right) \text {, protein }\left(1542 \mathrm{~cm}^{-1}\right)\end{array}$ \\
\hline Green-wood & $\begin{array}{l}\text { Gypsum }\left(3543,3405,1621,1154,1129,615 \text {, and } 595 \mathrm{~cm}^{-1}\right) \text {, protein }(1657,1541, \\
\left.\text { and } 1322 \mathrm{~cm}^{-1}\right) \text {, aliphatic }\left(2926 \text { and } 2856 \mathrm{~cm}^{-1}\right) \text {, lead carbonate }(1403 \text { and } \\
\left.674 \mathrm{~cm}^{-1}\right) \text {, Prussian blue }\left(2133 \mathrm{~cm}^{-1}\right) \text {, red lead }\left(512 \text { and } 465 \mathrm{~cm}^{-1}\right)\end{array}$ \\
\hline Green-cream & $\begin{array}{c}\text { Gypsum }\left(3543,3405,1621,1154,1129,615 \text {, and } 595 \mathrm{~cm}^{-1}\right) \text {, protein }(1655,1542, \\
\left.\text { and } 1322 \mathrm{~cm}^{-1}\right) \text {, aliphatic }\left(2926 \text { and } 2856 \mathrm{~cm}^{-1}\right) \text {, lead carbonate }(1403 \text { and } \\
\left.674 \mathrm{~cm}^{-1}\right) \text {, Prussian blue }\left(2133 \mathrm{~cm}^{-1}\right) \text {, red lead }\left(512 \text { and } 465 \mathrm{~cm}^{-1}\right)\end{array}$ \\
\hline
\end{tabular}

Vibrational frequencies assignment was completed by comparing the obtained spectra with the standard spectra for ground, pigments, and binders that we obtained. The presence of proteins is evidenced by the absorptions at $3000-2800 \mathrm{~cm}^{-1}$ and $\sim 1645 \mathrm{~cm}^{-1}$, also identifying the presence of egg yolk.

The employed painting materials included lead carbonate for white; red lead, arsenic red, and iron red for red; traces of Prussian blue; gypsum as ground; and proteins as binder.

The presence of gypsum and of oxalates was identified on, and in the wood (gypsum characteristic absorptions at 1157, 1120, and 700-500 $\mathrm{cm}^{-1}$ ) (Figure 8, right side). The oxalate presence in the wood-lichens sample was demonstrated, especially when the $1800-1300$ and $900-500 \mathrm{~cm}^{-1}$ spectral domains were analyzed (Figure 8, left side). The oxalate presence in the wood-lichens sample was demonstrated, especially when the $1800-1300$ and $900-500 \mathrm{~cm}^{-1}$ spectral domains were analyzed (Figure 8, right side).
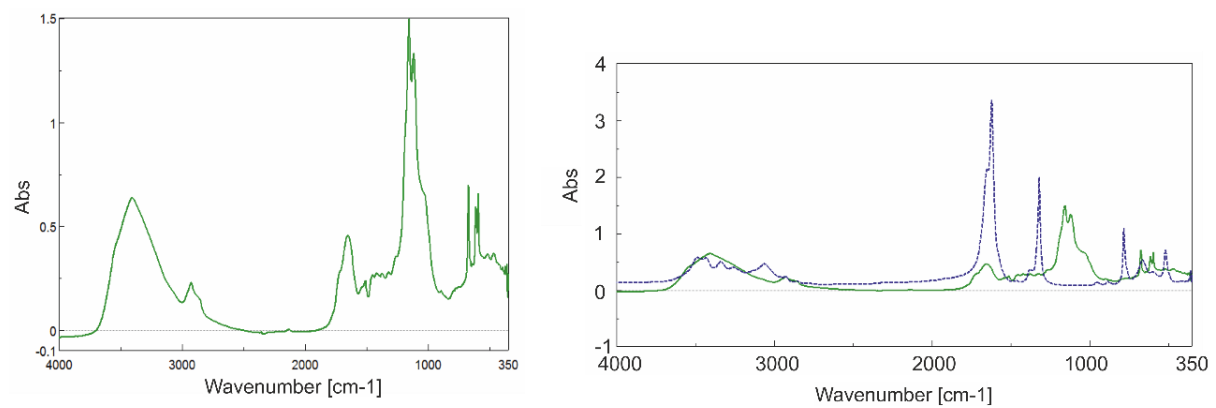

Figure 8. (left) FTIR spectrum of wood-lichens (continuous line) and (right) calcium oxalate (dashed line).

\subsection{Digitization}

To obtain a detailed 3D textured model of the Imperial Gates, the structured light scanner Creaform GO!50 (2015, Creaform, Lévis-Québec, Canada) was used. The main purpose of this step was to acquire an accurate 3D model of the Imperial Gates that can be used for digital restoration and dissemination purposes. After the first phase of digitization, the result was processed within CAD 
software (Catia V5) and digital content creation software (3D Studio Max) to obtain the final 3D model. The final model represents a digital replica of the Imperial Gates that can be successfully used in various virtual reality/mixed reality applications. The first step in the preservation of Imperial Gates was the digitization of the church interior using a Z+F IMAGER ${ }^{\circledR}$ 5010X (2015, Zoller + Fröhlich, Wangen, Germany) terrestrial laser scanner (TLS) (Figure 9), with a resolution range of $0.1 \mathrm{~mm}, 320^{\circ} \times 360^{\circ}$ field-of-view, with an HDR camera. The scanning of the interior of the church only served to digitally preserve the actual state of conservation of the wooden church. If the digitization of churches and their outside areas is required, digitization techniques must be combined. Normally, the TLS can be raised to a height of $5 \mathrm{~m}$ on the tripod, whereas an unmanned aerial vehicle (UAV) can be used for the upper elements of the church that are out of the scanner sight photogrammetry techniques, or other methods as previously presented.

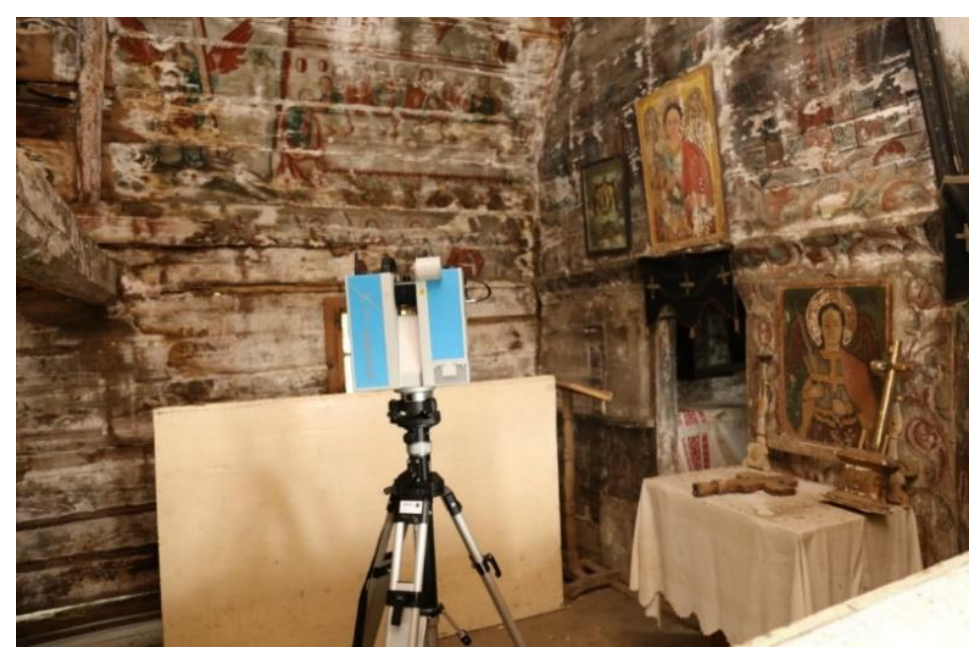

Figure 9. Terrestrial laser scanner used for digitization of actual conservation status.

The scanning parameters were: resolution—super high, quality—high, 42 images acquired for texture mapping, $80 \mathrm{Mpx}$ texture quality, points acquired—approximatively 6 million/scan position, and Smartlight activated. Seven points were used for scanning the interior, as shown in Figure 10. The first two positions overlapped; we used different resolutions and height for a better digitization of the Imperial Gates.

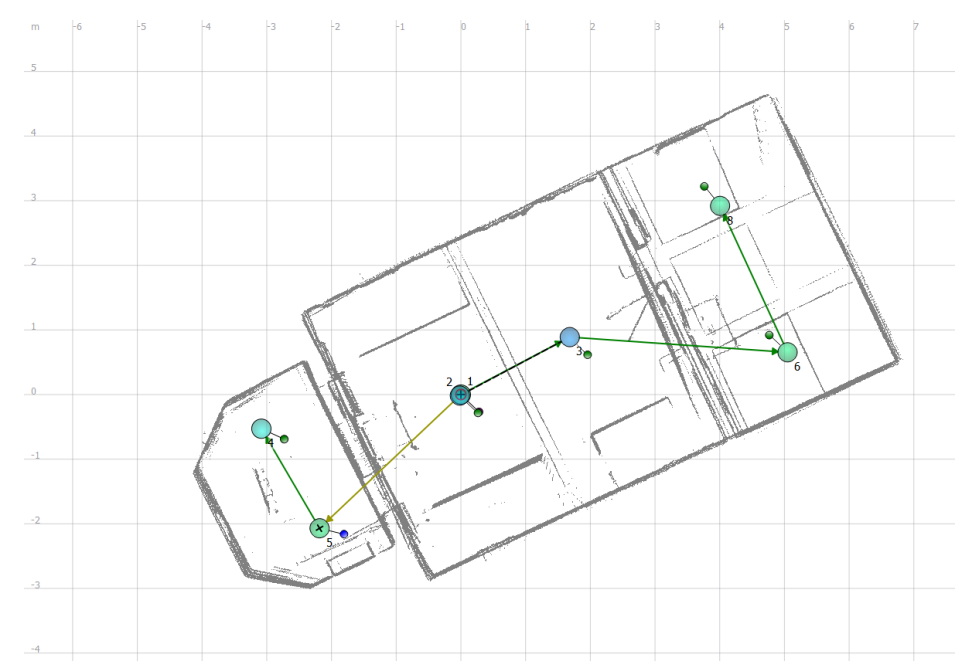

Figure 10. Scan positions for digitizing the wooden church. 
The results of digitization can be seen in Figure 11.

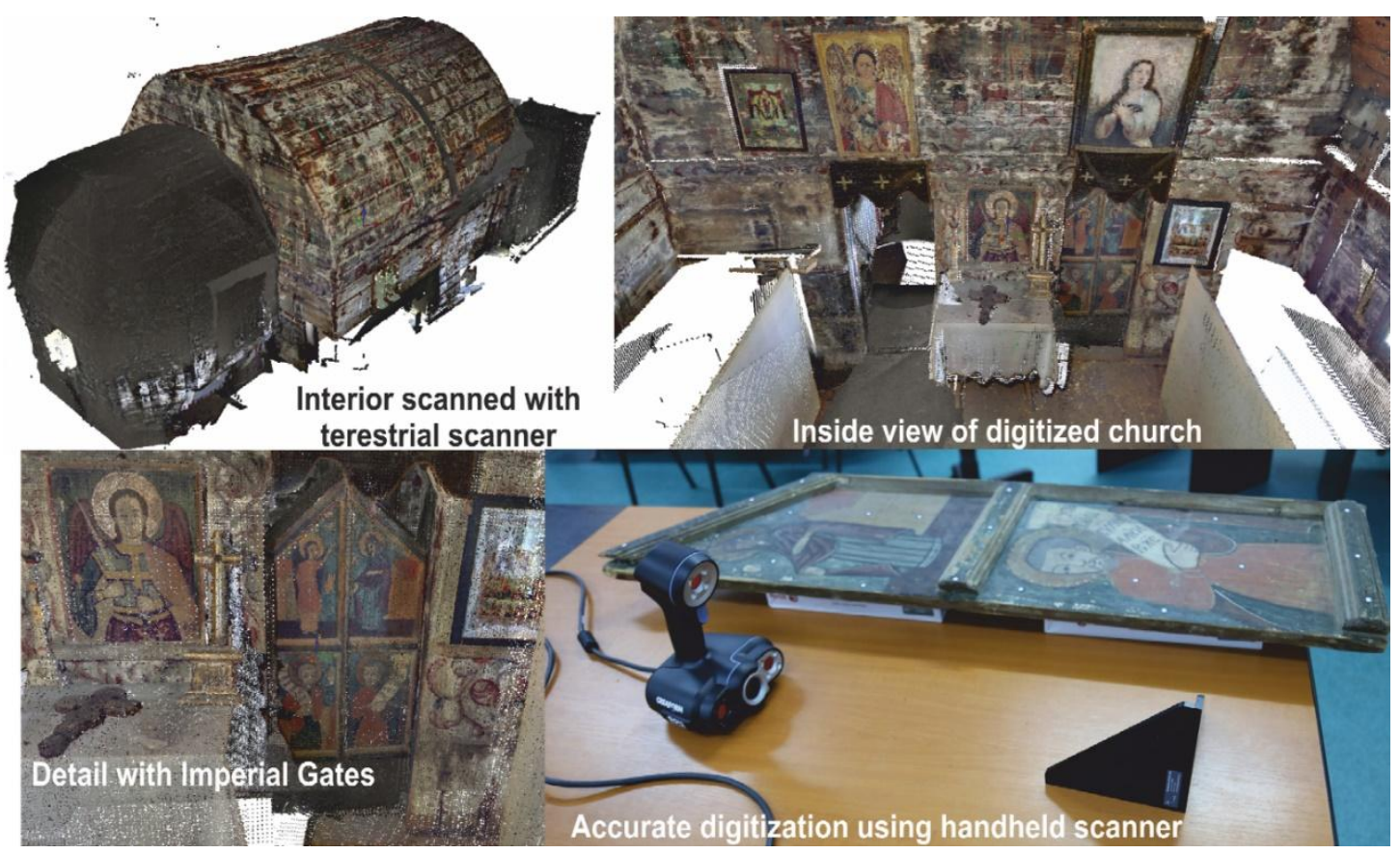

Figure 11. Digitization of the wooden church.

The second step in digital preservation of the Imperial Gates was their digitization using a high accuracy laser scanner. The GO!Scan 50 (Figure 12) scanner was used for a high-accuracy digitization, generating a mesh with $50 \mu \mathrm{m}$ precision on which the texture applied was $268 \mathrm{MPx}$. The result of the digitization process can be seen in Figure 13 (also Video S1). Both sides of the Imperial Gates were scanned using a single scanning session using the positioning targets (Figure 12) and advance scanning methods.

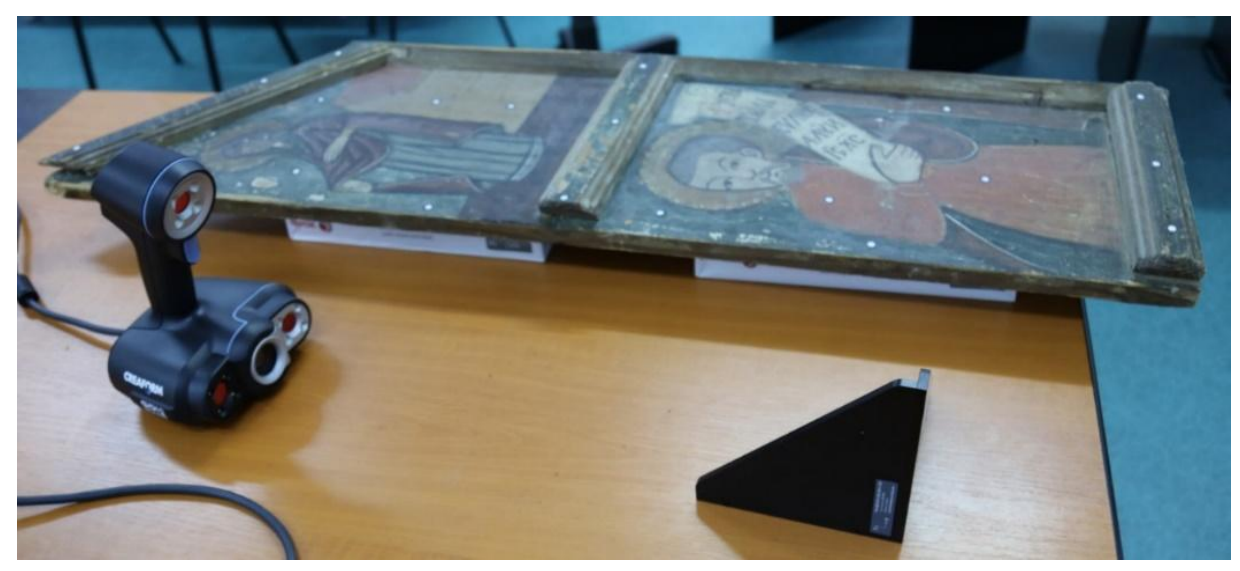

Figure 12. Digitization of Imperial Gates using a GO!Scan 50 scanner. 


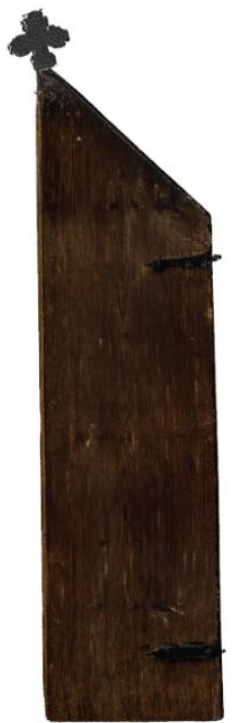

(a)

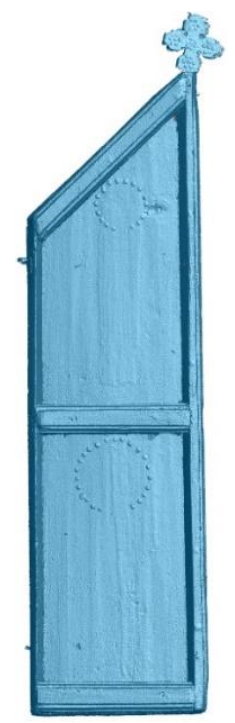

(b)

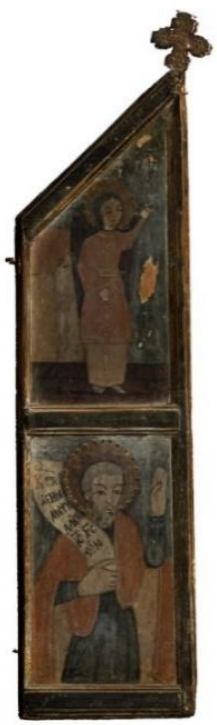

(c)

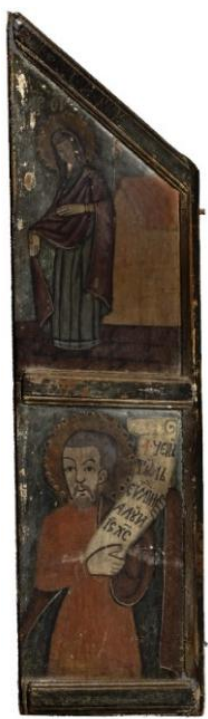

(d)

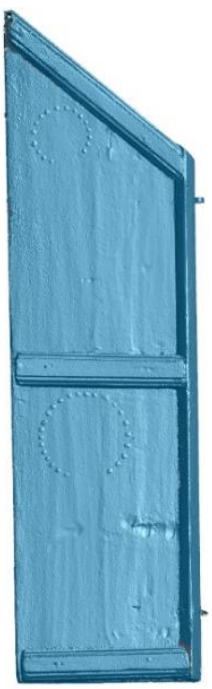

(e)

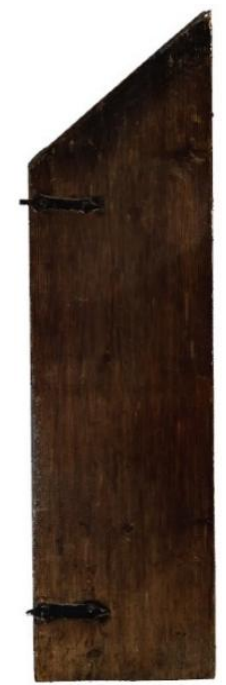

(f)

Figure 13. Imperial Gates digitized with GO!Scan 50 scanner: (a,f) back side, (b,e) three-dimensional (3D) model without texture, and (c,d) textured 3D model.

The next step was the digital restoration of the painted layer. Figure 14 illustrates the results of the digital restoration of the painting layer. The digital restoration accounted for two working hypotheses: one in which the painting layer is restored with the current nuances and one that uses the initial colors obtained based on the physico-chemical analyzes. Figure 14 also shows the result obtained for the second hypothesis.

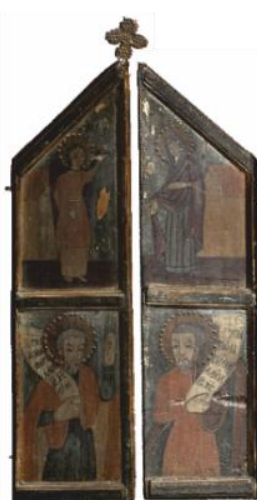

Digitized Imperial Gates

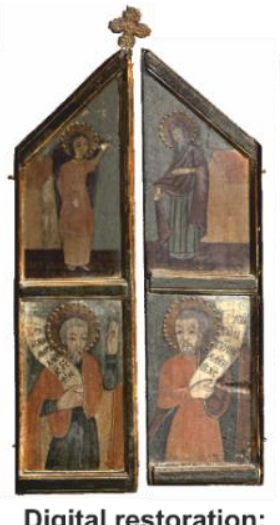

Digital restoration: "Classic Style"

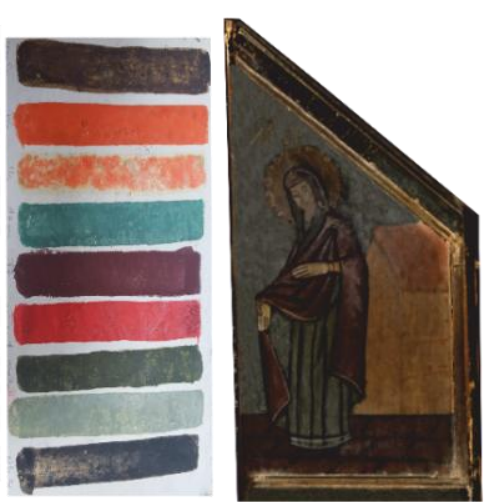

Original colors Digital restoration: "Classic Style"

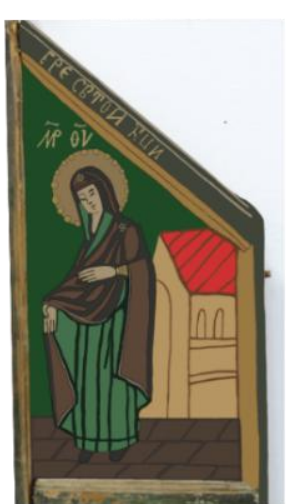

Digital restoration: "Original Color Style"

Figure 14. Imperial Gates before and after digital restoration of the painting layer.

Having completed the digital restoration process, the texture was processed and remaped on the mesh of the model to integrate the digital model of the Imperial Gates into a virtual museum. The virtual museum (Figure 15) was developed in Unity and can be accessed on smart devices like interactive tables, phones, tablets, augmented glasses, and virtual reality headsets. 


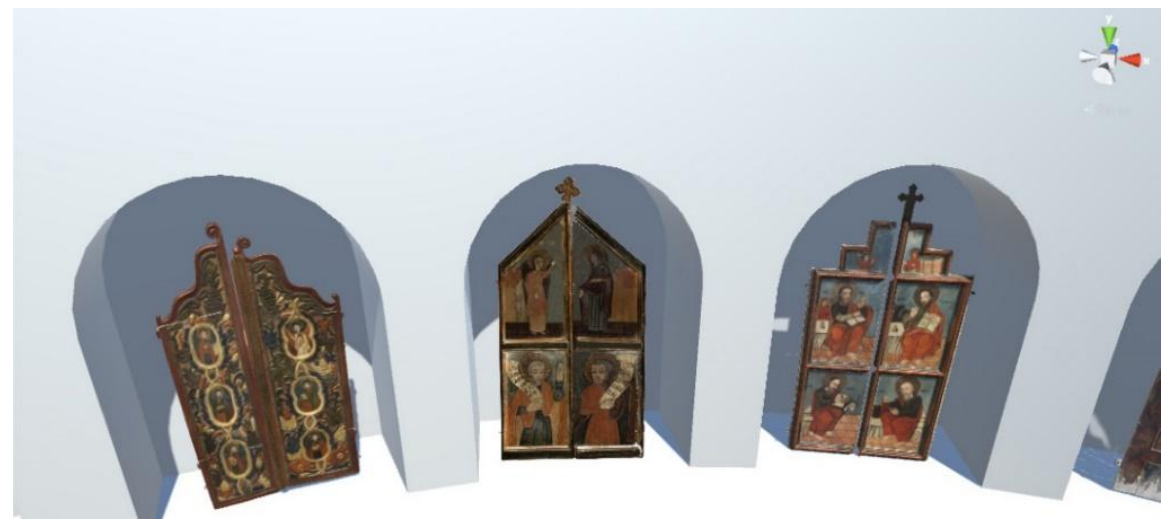

Figure 15. Virtual museum for the Imperial Gates.

Another form of promoting this cultural heritage was using the platform Sketchfab.com, where the users can visualize and interact with the 3D models using hot spots (Figure 16). This platform also offers support for immersive visualization using a virtual reality headset.

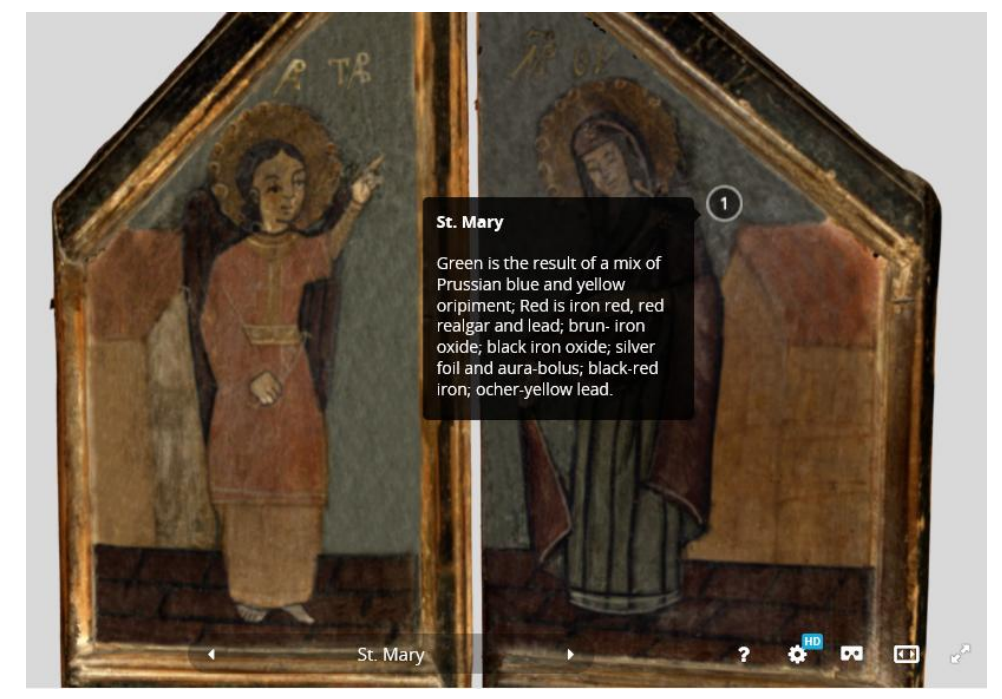

Figure 16. Imperial Gates with hotspot on Sketchfab.com.

\section{Discussion and Conclusions}

In our daily lives, we receive a mix of information from various digital media sources and the presence in this informational flux can be a success factor key to achieve a large audience. We believe that the presence of the Imperial Gates in the digital world can be the first step in their classic conservation and assist in the rescue and preservation of the wooden churches. Digitizing and publishing the Imperial Gates in an online 3D format increases the number of potential visitors to the churches where the Imperial Gates are located. We propose the digitization of as many Imperial Gates and wooden church interiors as possible so that they can be used in the online environment as marketing tools. Based on the 3D models available online and according to the interest of the tourists, theme cultural heritage trips could be organized.

The methodology presented is interdisciplinary in nature, and in this stage, the process cannot be automatized as it requires a high level of technical expertise, which, together with the cost factor, 3D data management could be a problem for large scale implementation [35].

FTIR spectroscopy established that lime was the wood used for the Imperial Gates. Oxalate presence was also detected in wood, including lichens systems, identifying the fungal attack on the wood. Based on XRF and FTIR data analyses, the composition of the painting materials was confirmed 
as: lead carbonate for white; red lead, red iron, and red arsenic for red; traces of Prussian blue; gypsum as ground; proteins as binder; yellow-orpiment; and halo-silver. The corresponding pigments for each color were identical for both sides of the Imperial Gates.

As shown in Figure 14, the original colors were obtained in the laboratory, then digitized and processed as in the methodology proposed by Korytkowski and Olejnik-Krugly [39]. Using a commercial solution for image processing, we repainted the missing part of the painting with the actual colors used for "classic style" restoration. We replaced the current colors with the original colors, which we synthetized on the basis of physico-chemical analyses. Having these two versions, we could observed the footprint of time and external factors that influenced the painting over the centuries.

The digitization of the Imperial Gates using laser scanners was the first step in the digital restoration procedure and an effective method of preserving the cultural heritage represented by the Imperial Gates. The highly accurate model of the digitized Imperial Gates, combined with the physico-chemical analysis, provided a complete dataset that can describe the current conservation state of the Imperial Gates. Digitization is required for preserving this current state in digital format and for digital restoration. The high-accuracy model of the digitized Imperial Gates can also be used for dissemination of cultural heritage using the Internet. The 3D model can be seen on the project website or on Sketchfab: digitization of Imperial Gates (https://skfb.ly/IS89) and digital restoration version (https://skfb.ly/6ozOn).

The preservation and restoration of the wooden churches enable the introduction of the Romanian villages into international travel tours.

Supplementary Materials: The following are available online at http:/ / www.mdpi.com/2071-1050/10/5/1503/ s1, Video S1: Result of digitization of the wooden church from Salisca.

Author Contributions: All authors contributed to writing the paper and reviewed the manuscript. V.C.M. and C.M. performed the XRF analysis and interpretation; I.C. performed the theological and artistic study; I.B. and O.F.M. performed the FTIR analysis and interpretation; C.N. and M.D. performed the 3D scanning and the 3D data processing; C.N. and D.P. realized the digital restoration in both classical and original color styles. M.D. and C.N. created the virtual museum; D.P. prepared Figures 1, 2 and 9; V.C.M. and C.M. prepared Figures 4-7 and Table 1; I.B. prepared Figures 3 and 8; I.B. and O.F.M. prepared Table 2; I.C. prepared Figure 1; M.D. prepared Figures 12, 15 and 16; C.N. prepared Figures 10, 11, 13 and 14.

Acknowledgments: This work was supported by a grant of the Romanian Ministry of Research and Innovation, CCCDI-UEFISCDI, project number PN-III-P1-1.2-PCCDI-2017-0812/53PCCDI, within PNCDI III.

Conflicts of Interest: The authors declare no conflict of interest. The founding sponsors (public institution) had no role in the design of the study; in the collection, analyses, or interpretation of data; in the writing of the manuscript, and in the decision to publish the results.

\section{References}

1. Iorga, N. Istoria Bisericii Româneşti şi a Vietii Religioase a Românilor; Tip. "Neamul Romănesc": Valenii de Munte, Romania, 1908; Volume 1.

2. Thomas, B.; Thomas, S.; Powell, L. The development of key characteristics of welsh island cultural identity and sustainable tourism in wales. Sci. Cult. 2017, 3, 23-39.

3. Romana, P. Biserica Românească din Transilvania în Secolele XIV-XVIII. Available online: http: / / patriarhia. ro/iii-b-biserica-romaneasca-din-transilvania-in-secolele-xiv-xviii-155.html (accessed on 16 January 2018).

4. 7MostEndangered. Wooden Churches in Southern Transylvania and Northern Oltenia, Romania. Available online: http:/ / $m$ mostendangered.eu/2014/05/04/wooden-churches-in-southern-transylvaniaand-northern-oltenia-romania/ (accessed on 24 January 2018).

5. Pădurean, A.; Herineanu, H. Protopopiatul Ortodox Român Dej; Editura Renașterea: Cluj-Napoca, Romania, 2010.

6. Nicolae, S. Biserici de lemn din podișul transilvano-someșean. In Monumente Istorice și de Artă Religioasă din Arhiepiscopia Vadului, Feleacului și Clujului; Pascu, Ș., Vataşianu, V., Porumb, M., Maramureșanul, J.C., Bărbulescu, M., Sabău, N., Mândrescu, G., Tarnovschi, B., Morar, A., Toș, I., Eds.; Editura Arhiepiscopiei Ortodoxe a Vadului, Feleacului și Clujului: Cluj-Napoca, Romania, 1982.

7. Shugar, A.N.; Mass, J.L. Handheld XRF for Art and Archaeology; Leuven University Press: Leuven, Belgium, 2012; Volume 3. 
8. Derrick, M.R.; Stulik, D.; Landry, J.M. Infrared Spectroscopy in Conservation Science; Getty Publications: Los Angeles, CA, USA, 2000.

9. Liritzis, I.; Al-Otaibi, F.; Kilikoglou, V.; Perdikatsis, V.; Polychroniadou, E.; Drivaliari, A. Mortar analysis of wall painting at amfissa cathedral for conservation-Restoration purposes. Mediterr. Archaeol. Archaeom. 2015, 15, 301-311.

10. Sackler, A.M. Scientific Examination of Art: Modern Techniques in Conservation and Analysis; The National Academies Press: Atlanta, GA, USA, 2005.

11. Marutoiu, C.; Laura, T.; Toader, V.-D.; Moldovan, Z.; Turza, A.I.; Tanaselia, C.; Bratu, I. Scientific investigation of pigments employed for crucifixion processional flag painting from the ethnographic museum of transylvania heritage. Stud. Univ. Babes-Bolyai Chem. 2013, 58, 161-172.

12. Bratu, I.; Siluan, M.; Măruţoiu, C.; Kacso, I.; Garabagiu, S.; Măruţoiu, V.; Tănăselia, C.; Popescu, D.; Postolache, D.; Pop, D. Science applied for the investigation of Imperial Gate from eighteenth century wooden church of Nicula monastery. J. Spectrosc. 2017, 6167856. [CrossRef]

13. Bratu, I.; Marutoiu, C.; Moldovan, Z.; Marutoiu, V.C.; Trosan, L.; Pop, D.T.; Sandu, I.C.A. Scientific investigation of the Saint Elijah's icon from Dragus Village, Brasov County for its preservation and restoration. Rev. Chim. 2015, 66, 1628-1631.

14. Baciu, A.; Moldovan, Z.; Bratu, I.; Marutoiu, O.; Kacsó, I.; Glajar, I.; Hernanz, A.; Marutoiu, C. Comparative study of the painting materials of a series of orthodox icons on wooden and glass support from Transylvania. Curr. Anal. Chem. 2010, 6, 53-59. [CrossRef]

15. Bratu, I.; Moldovan, Z.; Kacso, I.; Marutoiu, C.; Trosan, L.; Marutoiu, V.C. A transylvanian diptych wooden icon: Wooden support and painting materials investigations. Rev. Chim. 2013, 64, 524-528.

16. Bratu, I.; Marutoiu, C.; Trosan, L.; Moldovan, Z.; Kacso, I.; Toader, D. Complex investigation of component materials of triptych icon "mother of god" from the patrimony of Ethnographic Museum of Transylvania. Rev. Roum. Chim. 2014, 59, 1003-1008.

17. Marutoiu, C.; Grapini, S.; Baciu, A.; Miclaus, M.; Marutoiu, V.; Dreve, S.; Kacso, I.; Bratu, I. Scientific investigations of a 16th century stall belonging to the Evangelic Church in Bistriţa, Bistriţa-Năsăud County, Romania. J. Spectrosc. 2012, 2013, 957456. [CrossRef]

18. Marutoiu, C.; Bratu, I.; Trifa, A.; Botis, M.; Marutoiu, V. Ftir analysis of painting materials from the Church Saint Paraschiva, of Poienile Izei, Maramures, Romania. Int. J. Conserv. Sci. 2011, 2, 29-35.

19. Hernanz, A.; Bratu, I.; Marutoiu, O.; Marutoiu, C.; Gavira-Vallejo, J.; Edwards, H. Micro-raman spectroscopic investigation of external wall paintings from St. Dumitru's Church, Suceava, Romania. Anal. Bioanal. Chem. 2008, 392, 263-268. [CrossRef] [PubMed]

20. Alin, T.R.; Măruţoiu, C.; Şanta, G.; Bratu, I.; Măruţoiu, V.C. Research on the mural paintings from the church saints archangels, from the Village of Aşchileu Mic, County of Cluj. Eur. J. Sci. Theol. 2013, 9, 169-177.

21. Marutoiu, C.; Nica, L.; Bratu, I.; Marutoiu, O.F.; Moldovan, Z.; Neamtu, C.; Gardan, G.; Rauca, A.; Sandu, I.C.A. The scientific investigation of the Imperial Gates belonging to Sanmihaiul Almasului Wooden Church (1816). Rev. Chim. 2016, 67, 1739-1744.

22. Măruţoiu, C.; Bratu, I.; Troşan, L.; Neamtu, C.; Măruţoiu, V.; Pop, D.; Tănăselia, C.; Garabagiu, S. Scientific investigation of the imperial gates belonging to the Wooden Church from Săcel, Turda County, Romania. Spectrochim. Acta Part A Mol. Biomol. Spectrosc. 2016, 152, 311-317. [CrossRef] [PubMed]

23. Marutoiu, C.; Bratu, I.; Nemes, O.; Dit, I.-I.; Comes, R.; Tanaselia, C.; Falamas, A.; Miclaus, M.; Marutoiu, V.; Moraru, R. Instrumental analysis of materials and topology of the imperial gates belonging to the Apahida Wooden Church, Cluj County. Vib. Spectrosc. 2017, 89, 131-136. [CrossRef]

24. Marutoiu, C.; Bratu, I.; Budu, A.M.; Santa, G.; Marutoiu, O.F.; Neamtu, C.; Tanaselia, C.; Kacso, I.; Sandu, I.C.A. Evaluation of conservation state by analysis of imperial gates' constituent materials belonging to A Aschileu Mic Wooden Church, Cluj County. Rev. Chim. 2015, 66, 992-996.

25. Salama, K.; Ali, M.; El-Shiekh, S. Reconstruction of monastery Saint Jeremiah computer-aided design model. Sci. Cult. 2017, 3, 4.

26. Comes, R. Haptic devices and tactile experiences in museum exhibitions. J. Anc. Hist. Archaeol. 2016, 3, 61-64. [CrossRef]

27. Neamtu, C.; Comes, R. Methodology to create digital and virtual 3D artefacts in archaeology. J. Anc. Hist. Archaeol. 2016, 3, 65-74. [CrossRef] 
28. Glavcheva, Z.; Yancheva, D.; Kancheva, Y.; Velcheva, E.; Stamboliyska, B. Development of ftir spectra database of reference art and archaeological materials. Bulg. Chem. Commun. 2014, 46, 164-169.

29. Buna, Z.; Popescu, D.; Comes, R.; Badiu, I.; Mateescu, R. Engineering cad tools in digital archaeology. Mediterr. Archaeol. Archaeom. 2014, 14, 83-91.

30. D'Agnano, F.; Balletti, C.; Guerra, F.; Vernier, P. Tooteko: A case study of augmented reality for an accessible cultural heritage. Digitization, 3D printing and sensors for an audio-tactile experience. Int. Arch. Photogramm. Remote Sens. Spat. Inf. Sci. 2015, 40, 207. [CrossRef]

31. Bratu, I.; Paduraru, M.; Marutoiu, C.; Pop, S.S.F.; Kacso, I.; Tanaselia, C.; Marutoiu, O.F.; Sandu, I.C.A. Multianalytical study on two wooden icons from the beginning of the eighteenth century evaluation of conservation state. Rev. Chim. 2016, 67, 2383-2388.

32. Dragomir, M.; Banyai, D.; Dragomir, D.; Popescu, F.; Criste, A. Efficiency and resilience in product design by using morphological charts. Energy Procedia 2016, 85, 206-210. [CrossRef]

33. Sorin, P.; Diana, P.; Mihai, D. Creativity, idea management and innovation-prerequisites for new product development in a furniture start-up. In Proceedings of the 2014 International Conference on Production Research-Regional Conference Africa, Europe and the Middle East and 3rd International Conference on Quality and Innovation in Engineering and Management, Cluj-Napoca, Romania, 1-5 July 2014.

34. Scurtu, L.-I.; Ștefan, B.; Dragomir, M. Optimization methods applied in CAD based furniture design. Acta Tech. Napoc.-Ser. Appl. Math. Mech. Eng. 2015, 58, 559-562.

35. Tsiafaki, D.; Michailidou, N. Benefits and problems through the application of 3D technologies in archaeology: Recording, visualisation, representation and reconstruction. Sci. Cult. 2015, 1, 37-45.

36. Liritzis, I.; Al-Otaibi, F.M.; Volonakis, P.; Drivaliari, A. Digital technologies and trends in cultural heritage. Mediterr. Archaeol. Archaeom. 2015, 15, 313-332.

37. Liritzis, I.; Pavlidis, G.; Vosynakis, S.; Koutsoudis, A.; Volonakis, P.; Petrochilos, N.; Howland, M.D.; Liss, B.; Levy, T.E. Delphi4delphi: First results of the digital archaeology initiative for ancient Delphi, Greece. Antiquity 2016, 90, e4. [CrossRef]

38. Hatzopoulos, J.N.; Stefanakis, D.; Georgopoulos, A.; Tapinaki, S.; Pantelis, V.; Liritzis, I. Use of various surveying technologies to 3D digital mapping and modelling of cultural heritage structures for maintenance and restoration purposes: The tholos in Delphi, Greece. Mediterr. Archaeol. Archaeom. 2017, 17, 311-336.

39. Korytkowski, P.; Olejnik-Krugly, A. Precise capture of colors in cultural heritage digitization. Color Res. Appl. 2017, 42, 333-336. [CrossRef]

40. Piccialli, F.; Chianese, A. Cultural heritage and new technologies: Trends and challenges. Pers. Ubiquitous Comput. 2017, 21, 187-189. [CrossRef]

41. Casteret, J.J. Digitisation as a "place" of safeguarding for the intangible cultural heritage. In Situ Rev. Patrim. 2017, 33. [CrossRef]

(C) 2018 by the authors. Licensee MDPI, Basel, Switzerland. This article is an open access article distributed under the terms and conditions of the Creative Commons Attribution (CC BY) license (http://creativecommons.org/licenses/by/4.0/). 